\title{
Xanthones from a microfungus of the genus Xylaria
}

Peter C. Healy ${ }^{\mathrm{a}}$, Ailsa Hocking ${ }^{\mathrm{b}}$, Nai Tran-Dinh ${ }^{\mathrm{b}}$, John I. Pitt ${ }^{\mathrm{b}}$, Roger G. Shivas ${ }^{\mathrm{c}}$, Jennifer K. Mitchell ${ }^{\mathrm{a}}$, Mike Kotiw ${ }^{\mathrm{d}}$, Rohan A. Davis ${ }^{\mathrm{a}, *}$

${ }^{a}$ Chemical Biology Program, Eskitis Institute, Griffith University, Brisbane, QLD 4111, Australia

${ }^{\mathrm{b}}$ Food Science Australia, P.O. Box 52, North Ryde, NSW 1670, Australia

${ }^{\mathrm{c}}$ Department of Primary Industries and Fisheries, 80 Meiers Road, Indooroopilly, QLD 4068, Australia

${ }^{\mathrm{d}}$ Department of Biological and Physical Sciences, University of Southern Queensland, Toowoomba, QLD 4351, Australia

${ }^{*}$ Corresponding author. Tel.: +61 73875 7587; fax: +61 73875 7656; e-mail: r.davis@griffith.edu.au 


\begin{abstract}
Chemical investigations of a microfungus Xylaria sp. isolated from the Australian rainforest tree Glochidion ferdinandi have afforded two new natural products, 2-hydroxy6-methyl-8-methoxy-9-oxo-9H-xanthene-1-carboxylic acid (1) and 2-hydroxy-6hydroxymethyl-8-methoxy-9-oxo-9H-xanthene-1-carboxylic acid (2). Compound $\mathbf{1}$ has previously been synthesised but only partially characterised. Methylation of 1 using diazomethane afforded the crystalline compound 2,8-dimethoxy-6-methyl-9-oxo-9Hxanthene-1-carboxylic acid methyl ester (3), whose structure was determined by single crystal X-ray analysis. This paper reports the full spectroscopic characterisation of compounds 1-3 by NMR, UV, IR and MS data. All compounds were inactive in a brine shrimp lethality assay and several antimicrobial screens.
\end{abstract}

\title{
Keywords
}

Microfungus; Xylaria sp.; Rainforest tree; Glochidion ferdinandi; Natural products; Secondary metabolites; Xanthone 


\section{Introduction}

Xanthones are a class of natural products that have been shown to display a wide range of pharmacological properties (Peres and Nagem, 1996; Peres et al., 2000). Reported biological activities included anticancer (Ho et al., 2002), antifungal (Rocha et al., 1994), antioxidant (Minami et al., 1994) antimicrobial (Malet-Cascon et al., 2003), antiinflammatory (Lin et al., 1996) and antiviral (Groweiss et al., 2000). The majority of xanthones reported in the literature have been isolated from higher plants, especially those belonging to the families Gentianaceae and Clusiaceae (Peres and Nagem, 1996; Peres et al., 2000). However, fungi and lichens have also been sources of this class of secondary metabolite (Huneck, 2001; Schulz et al., 2002). Microfungi belonging to the genus Xylaria have been previously investigated for their chemistry and have proven to be a good source of bioactive compounds. Examples include the chemokine receptor (CCR5) antagonist 19,20-epoxycytochalsin Q (Jayasuriya et al., 2004), the antifungal metabolites multiplolides A and B (Boonphong et al., 2001) and the NPY Y5 receptor antagonists xylarenals A and B (Smith et al., 2002). We have recently embarked on a research program looking for new chemistry and bioactive metabolites from microfungi isolated from Australian endemic plants. Examination of a local rainforest tree, Glochidion ferdinandi (family Euphorbiaceae) afforded several microfungal strains, one of which was identified as Xylaria sp. This strain was fermented on solid media and chemical investigations of the resulting culture have resulted in the isolation of two new natural product xanthones, 2-hydroxy-6-methyl-8-methoxy-9-oxo-9H-xanthene-1- 
carboxylic acid (1) and 2-hydroxy-6-hydroxymethyl-8-methoxy-9-oxo-9H-xanthene-1carboxylic acid (2).

\section{Results and Discussion.}

The fungus Xylaria sp. (FRR 5657) was grown on damp white rice under static conditions then extracted with EtOAc. This extract was separated by $\mathrm{C} 18$ flash column chromatography using $\mathrm{H}_{2} \mathrm{O}$ and increasing amounts of $\mathrm{MeOH}$ and yielded pure 2hydroxy-6-methyl-8-methoxy-9-oxo-9H-xanthene-1-carboxylic acid $(1,37 \mathrm{mg})$ following precipitation from the $60 \% \mathrm{MeOH} / 40 \% \mathrm{H}_{2} \mathrm{O}$ elution. An early eluting fraction from the flash column was subjected to $\mathrm{C} 18$ preparative $\mathrm{HPLC}\left(\mathrm{MeOH} / \mathrm{H}_{2} \mathrm{O}\right)$ followed by gel permeation chromatography using Sephadex LH-20 (MeOH) to afford pure 2-hydroxy-6hydroxymethyl-8-methoxy-9-oxo-9H-xanthene-1-carboxylic acid (2, $4.3 \mathrm{mg})$.

The major metabolite, 2-hydroxy-6-methyl-8-methoxy-9-oxo-9H-xanthene-1carboxylic acid (1) was isolated as a pale yellow amorphous solid. A pseudomolecular ion in the (-)-HRESIMS at $\mathrm{m} / \mathrm{z} 299.0555$ allowed a molecular formula of $\mathrm{C}_{16} \mathrm{H}_{12} \mathrm{O}_{6}$ to be assigned to 1. Broad IR absorptions at 3500-3000 and $1625 \mathrm{~cm}^{-1}$ indicated the presence of hydroxyl and carbonyl groups, respectively. The presence of a phenol within compound 1 was established based on the UV spectrum, which underwent a bathochromic shift on addition of base. The ${ }^{1} \mathrm{H}$ NMR spectrum (Table 1) of $\mathbf{1}$ contained two exchangeable singlets [ $\delta 12.49(1 \mathrm{H})$ and $9.96(1 \mathrm{H})]$, two mutually-coupled aromatic doublets $[\delta 7.43(\mathrm{~d}, J=9.0 \mathrm{~Hz}, 1 \mathrm{H})$ and $7.29(\mathrm{~d}, J=9.0 \mathrm{~Hz}, 1 \mathrm{H})]$, two aromatic singlets [ $66.91(1 \mathrm{H})$ and $6.78(1 \mathrm{H})]$ a methoxyl singlet $[\delta 3.86(3 \mathrm{H})]$ and an aromatic methyl singlet $[\delta 2.41(3 \mathrm{H})] . \quad$ The ${ }^{13} \mathrm{C}$ NMR spectrum displayed 16 signals of which 14 
resonated between 107 and 174 ppm suggesting a polyaromatic system. DEPT analysis revealed resonances for four aromatic methines (107.1, 109.2, 118.4 and $123.2 \mathrm{ppm})$, one methoxyl (56.0 ppm) and a methyl signal (21.8 ppm). The HSQC spectra enabled all the proton signals to be assigned to their directly attached carbons. The aromatic methyl (6$\mathrm{CH}_{3}$ ) at $\delta 2.41$ was positioned ortho to both aromatic methine protons at $\delta 6.78$ and 6.91 due to strong HMBC correlations to C-5 (109.2 ppm) and C-6 (107.1 ppm), respectively. ROESY correlations between 6- $\mathrm{CH}_{3}$ and $\mathrm{H}-5$ and $\mathrm{H}-7$ further supported this assignment. The methoxyl group at $\delta 3.86\left(8-\mathrm{OCH}_{3}\right)$ was positioned ortho to $\mathrm{H}-7(\delta 6.78)$ based on HMBC correlations from both sets of protons to C-8 (159.7 ppm) and a strong ROESY correlation between the proton singlets, $\delta 3.86$ and 6.78. The remaining portion of ring $\mathrm{B}$ contained an oxygen substituted quaternary carbon at C-4b (156.9 ppm) and a carbonyl substituent at C-8a (109.0 ppm). Weak HMBC correlations $\left({ }^{4} J_{\mathrm{CH}}\right)$ from both $\mathrm{H}-5$ and $\mathrm{H}-$ 7 to a carbonyl carbon at 173.5 ppm supported this substitution pattern. Ring A contained the pair of ortho-coupled $(J=9.0 \mathrm{~Hz})$ aromatic protons at $\delta 7.29(\mathrm{H}-3)$ and $7.43(\mathrm{H}-4)$. HMBC correlations from $\mathrm{H}-4$ to carbons resonating at $147.9 \mathrm{ppm}(\mathrm{C}-4 \mathrm{a})$ and 150.0 ppm (C-2) suggested two oxygenated quaternary carbons within ring B. The latter signal (C-2) was assigned to a phenol carbon based on a strong ROESY correlation between 2-OH $(\delta 9.96)$ and $\mathrm{H}-3(\delta 7.29)$. HMBC correlations from H-4 to C-9a (119.6 ppm) and C-9 (173.5 ppm) established a carbonyl meta-substitution of ring A relative to $\mathrm{H}-4$. HMBC correlations from $\mathrm{H}-3(\delta 7.29)$ to $\mathrm{C}-1(119.9 \mathrm{ppm})$ and $1-\mathrm{CO}_{2} \mathrm{H}(167.8$ ppm) established the substitution of a carboxylic acid moiety at position $\mathrm{C}-1$ of ring $\mathrm{A}$. With all the carbon and oxygen atoms of compound $\mathbf{1}$ accounted for the only remaining structural assignment was an ether bridge between $\mathrm{C}-4 \mathrm{a}$ and $\mathrm{C}-4 \mathrm{~b}$, which established two 
linkages between rings A and B and hence structure 1 was assigned to 2-hydroxy-6methyl-8-methoxy-9-oxo-9H-xanthene-1-carboxylic acid. Compound $\mathbf{1}$ is the 8-methyl ether analogue of the previously isolated fungal metabolite pinselic acid (4), which along with its methyl ester derivative pinselin (5) were both isolated from Penicillium amarum (Munekata, 1943, 1953) Pinselin has also been isolated from the plant Cassia occidentalis and is also known in the literature as cassiollin (5) (Ginde et al., 1970; Moppett, 1971). Compound 1 has previously been synthesised as an intermediate in the total synthesis of pinselic acid (4) and pinselin (5), however 1 was only partially characterised with no ${ }^{13} \mathrm{C}$ NMR data reported (Law et al., 1979).

Our attempts to obtain crystalline material of $\mathbf{1}$ suitable for single crystal X-ray analysis proved unsuccessful. However the methylation of 1 using $\mathrm{CH}_{2} \mathrm{~N}_{2}-\mathrm{Et}_{2} \mathrm{O}$ in $\mathrm{MeOH}$ at $0{ }^{\circ} \mathrm{C}$ afforded pure 2,8-dimethoxy-6-methyl-9-oxo-9H-xanthene-1-carboxylic acid methyl ester (3, $8.0 \mathrm{mg}, 98 \%$ yield), which yielded yellow needles $\left(\mathrm{CHCl}_{3}\right)$ suitable for X-ray analysis. The structure of $\mathbf{3}$ was established as 2,8-dimethoxy-6-methyl-9-oxo9H-xanthene-1-carboxylic acid methyl ester by X-ray crystallography. An ORTEP-3 (Farrugia, 1997) representation of the molecule is shown in figure 2. As for the previously reported crystal structure of 8-hydroxy-6-methyl-9-oxo-9H-xanthene-1carboxylic acid methyl ester (Macias et al., 2001) molecule 3 is planar except for the ester group which lies normal to the molecular plane with the $\mathrm{C} 2-\mathrm{C} 1-\mathrm{C} 1 \mathrm{a}-\mathrm{O} 1 \mathrm{~b}$ torsion angle of $81.4(5)^{\circ}$. Bond lengths and angles in the molecule are in accord with normal values (Allen et al., 1987). Compound 3 is the dimethyl ether of pinselin and has been previously produced by de novo synthesis (Law et al., 1979; Telange et al., 1977) and via methylation of pinselin (5) (Munekata, 1943), however the crystal structure and full 
NMR assignments for this metabolite have never been reported. NMR chemical shifts were assigned to structure 3 following analysis of ${ }^{1} \mathrm{H},{ }^{13} \mathrm{C}$, gCOSY, HSQC, gHMBC and ROESY NMR data.

The minor metabolite 2-hydroxy-6-hydroxymethyl-8-methoxy-9-oxo-9Hxanthene-1-carboxylic acid (2) was isolated as a stable yellow amorphous solid. An [M$\mathrm{H}]^{-}$ion in the (-)-HRESIMS at $\mathrm{m} / \mathrm{z} 315.0516$ allowed a molecular formula of $\mathrm{C}_{16} \mathrm{H}_{12} \mathrm{O}_{7}$ to be assigned to 2 . The UV and IR data for $\mathbf{2}$ was essentially identical to that of $\mathbf{1}$ and the presence of a phenol substituent was confirmed by the bathochromic shift identified in the UV spectrum of $\mathbf{2}$ on addition of base. The ${ }^{1} \mathrm{H}$ NMR spectral features of $\mathbf{2}$ were also similar to 1, however 2 lacked the downfield exchangeable signals and the aromatic methyl resonance present in $\mathbf{1}$. Compound $\mathbf{2}$ also contained two new mutually coupled proton signals at $\delta 4.59(\mathrm{~d}, J=5.5 \mathrm{~Hz}, 2 \mathrm{H})$ and $\delta 5.43(\mathrm{t}, J=5.5 \mathrm{~Hz}, 1 \mathrm{H})$. HSQC analysis assigned the protons at $\delta 4.59$ to a carbon at $62.4 \mathrm{ppm}$. This NMR data suggested the presence of a hydroxylmethylene moiety (Pretsch et al., 2000). Strong HMBC correlations from $\mathrm{H}-5(\delta 6.96)$ and $\mathrm{H}-7(\delta 6.84)$ of ring B to the carbon at 62.4 ppm indicated that 2 had the hydroxylmethylene group positioned at C-6. Strong ROESY correlations between both H-5 and H-7 and the methylene protons of 6- $\mathrm{CH}_{2} \mathrm{OH}$ further supported this assignment. Hence the structure for $\mathbf{2}$ was assigned to 2-hydroxy6-hydroxymethyl-8-methoxy-9-oxo-9H-xanthene-1-carboxylic acid. Compound 2 has the same oxygenation pattern and hydroxymethyl substitution to that of sydowinin B (6), which was isolated from the microfungus Aspergillus sydowi (Hamasaki et al., 1975).

Compounds 1-3 were all tested for toxicity in a brine shrimp (Artemia salina) lethality assay (Solis et al., 1993) and showed no activity at 20 or $200 \mu \mathrm{g} / \mathrm{mL}$. 
Antimicrobial activities for compounds 1-3 were also evaluated using a modified Kirby-Bauer agar diffusion assay (Greenberg et al., 1986) conducted at 12.5 and 6.25 $\mu \mathrm{g} /$ well against Escherichia coli (NCCLS N25922), Streptococcus pneumoniae (NCCLS N49619), Enterococcus faecalis (NCCLS N27853), Pseudomonas aeruginosa (NCCLS N27853), Staphylococcus aureus (ATCC 49476) and Candida albicans (ATCC 14053). No antimicrobial activity was observed for any of the xanthones 1-3. Further biological investigations of compounds 1-3 are currently underway.

\section{Experimental}

\subsection{General}

NMR spectra were recorded at $30{ }^{\circ} \mathrm{C}$ on a Varian $500 \mathrm{MHz}$ Unity INOVA at 499.923 MHz for ${ }^{1} \mathrm{H}$ and $124.981 \mathrm{MHz}$ for ${ }^{13} \mathrm{C}$. The ${ }^{1} \mathrm{H}$ and ${ }^{13} \mathrm{C}$ chemical shifts were referenced to the solvent peak for DMSO- $d_{6}$ at $\delta 2.49$ and $39.51 \mathrm{ppm}$, respectively. HRESIMS were recorded on a Bruker $4.7 \mathrm{~T}$ Apex III fourier-transform mass spectrometer. Melting points were determined using a Gallenkamp digital melting point apparatus and were uncorrected. FTIR and UV spectra were recorded on a Perkin-Elmer 1725X spectrophotometer and a GBC UV/vis 916 spectrophotometer, respectively. A Waters 600 pump equipped with a Waters 996 PDA detector and a Waters 717 autosampler were used for HPLC. Alltech Davisil 40-60 $\mu \mathrm{m} 60 \AA$ A $\mathrm{C} 18$ bonded silica packed into an open glass column $(35 \mathrm{~mm} \times 50 \mathrm{~mm})$ was used for flash chromatography. An SPE cartridge $(10 \mathrm{~mm} \times 30 \mathrm{~mm})$ packed with Alltech Davisil 40-60 $\mu \mathrm{m} 60 \AA$ Aiol bonded silica was used for synthetic reaction purification. Sephadex LH-20 packed into 
an open glass column $(35 \mathrm{~mm} \times 480 \mathrm{~mm})$ was used for gel permeation chromatography.

A Thermo Hypersil C18 BDS $5 \mu \mathrm{m} 143 \AA$ A preparative column $(21.2 \mathrm{~mm} \times 150 \mathrm{~mm})$ was used for HPLC separations. All solvents used for chromatography, UV and MS were Lab-Scan HPLC grade, and the $\mathrm{H}_{2} \mathrm{O}$ used was Millipore Milli-Q PF filtered. All synthetic reagents used were purchased from Sigma-Aldrich. All fungal culture media was purchased from Difco.

\subsection{Collection and identification}

Xylaria sp. was isolated from a surface sterilised (EtOH/flame) piece of outer bark from the rainforest tree Glochidion ferdinandi (Williams et al., 1984) collected from Toohey Forest, Queensland, Australia during February of 2003. Fungal voucher specimens FRR 5657 and BRIP 39875 have been deposited at Food Science Australia, North Ryde NSW 1670 and the Department of Primary Industries and Fisheries, Indooroopilly, QLD 4068, respectively. Xylaria sp. did not sporulate under a variety of different growing conditions hence morphological taxonomic studies were not possible. Fungal identification was carried out by sequencing of the fungal ribosomal RNA genes (ITS1, 5.8s and ITS2 regions) and sequence comparisons were made using BLASTN searches through the NCBI website (www.ncbi.nlm.nih.gov). The best scores for sequence matches were with fungi from the genus Xylaria.

\subsection{Fermentation, extraction and isolation}


The fungal isolate was initially grown in three culture tubes each containing malt extract broth $(10 \mathrm{~mL})$ at $30^{\circ} \mathrm{C}$ for 5 days. These cultures were transferred to three conical flasks (500 $\mathrm{mL})$ each containing damp white rice $\left(50 \mathrm{~g}\right.$ rice plus $\left.100 \mathrm{~mL} \mathrm{H}_{2} \mathrm{O}\right)$ and the fermentation was allowed to proceed under static conditions at $25^{\circ} \mathrm{C}$ for 28 days. EtOAc extraction of the cultures followed by removal of the solvent in vacuo yielded a dark green gum $(1.57 \mathrm{~g})$. This extract was pre-absorbed to C18 silica overnight then loaded onto a $\mathrm{C} 18$ flash column and a $20 \%$ stepwise gradient was performed from $100 \% \mathrm{H}_{2} \mathrm{O}$ to $100 \% \mathrm{MeOH}$. The $60 \% \mathrm{MeOH} / 40 \% \mathrm{H}_{2} \mathrm{O}$ elution was allowed to slowly evaporate over 2 days and a fine amorphous precipitate formed. This solid was filtered and dried to yield pure 2-hydroxy-6-methyl-8-methoxy-9-oxo-9H-xanthene-1-carboxylic acid (1, 37 mg). The $20 \% \mathrm{MeOH} / 80 \% \mathrm{H}_{2} \mathrm{O}$ elution was evaporated to dryness and the resulting material (136 mg) was subjected to $\mathrm{C} 18$ preparative chromatography using a linear gradient from $100 \% \mathrm{H}_{2} \mathrm{O}$ to $50 \% \mathrm{MeOH} / 50 \% \mathrm{H}_{2} \mathrm{O}$ in $50 \mathrm{~min}$ and a flowrate of $8 \mathrm{~mL} / \mathrm{min}$. Fraction $13\left(15 \mathrm{mg}, t_{\mathrm{R}}=32-37 \mathrm{~min}\right)$ was further purified using a Sephadex LH-20 column using $100 \% \mathrm{MeOH}$ as eluant at a flowrate of $4 \mathrm{~mL} / \mathrm{min}$. Analysis of the resulting fraction by (-)-LRESIMS and combining of the relevant test-tubes afforded pure 2hydroxy-6-hydroxymethyl-8-methoxy-9-oxo-9H-xanthene-1-carboxylic acid (2, $4.3 \mathrm{mg})$.

\subsubsection{2-Hydroxy-6-methyl-8-methoxy-9-oxo-9H-xanthene-1-carboxylic acid (1)}

Stable pale yellow amorphous solid; UV (MeOH) $\lambda_{\max }(\log \varepsilon) 245$ (4.20), 257 (4.23), 288 (3.69), $312 \mathrm{sh}$ (3.38), $371 \mathrm{~nm}(3.53) ; \mathrm{UV}(\mathrm{MeOH}+\mathrm{NaOH}) \lambda_{\max }(\log \varepsilon) 207$ (4.46), 259 (4.29), $412 \mathrm{~nm}(3.34) ; \quad I R v_{\max }(\mathrm{NaCl}) 3500-3000,1625,1569,1471,1392,1314$, 
$1227,1209,1107,1016,952,897,844,814,667 \mathrm{~cm}^{-1} ;{ }^{1} \mathrm{H}$ and ${ }^{13} \mathrm{C}$ NMR data see Table

1; (-)-LRESIMS m/z (rel. int.) 255 (25), 299 (100); (-)-HRESIMS m/z 299.0555

$\left(\mathrm{C}_{16} \mathrm{H}_{11} \mathrm{O}_{6}[\mathrm{M}-\mathrm{H}]^{-}\right.$requires 299.0561).

3.3.2 2-Hydroxy-6-hydroxymethyl-8-methoxy-9-oxo-9H-xanthene-1-carboxylic acid (2)

Stable pale yellow amorphous solid; UV (MeOH) $\lambda_{\max }(\log \varepsilon) 244(4.01), 258$ (4.01), 287 (3.51), $312 \mathrm{sh}$ (3.18), $369 \mathrm{~nm}$ (3.20); UV (MeOH+NaOH) $\lambda_{\max }(\log \varepsilon) 207$ (4.69), 259 (4.10), $412 \mathrm{~nm}(3.26)$; IR $v_{\max }(\mathrm{NaCl}) 3500-3035,1651,1567,1557,1539$, 1506, 1471, 1455, 1367, 1271, 1205, 1093, 1059, $819 \mathrm{~cm}^{-1} ;{ }^{1} \mathrm{H}$ and ${ }^{13} \mathrm{C}$ NMR data see Table 1; (-)-LRESIMS m/z (rel. int.) 271 (25), 315 (100); (-)-HRESIMS m/z 315.0516 $\left(\mathrm{C}_{16} \mathrm{H}_{11} \mathrm{O}_{7}[\mathrm{M}-\mathrm{H}]^{-}\right.$requires 315.0511).

\subsubsection{2,8-Dimethoxy-6-methyl-9-oxo-9H-xanthene-1-carboxylic acid methyl ester (3)}

Xanthone 1 (7.4 mg, $0.0246 \mathrm{mmol})$ was dissolved in dry $\mathrm{MeOH}(1.5 \mathrm{~mL})$ and $\mathrm{Et}_{2} \mathrm{O}(1.5 \mathrm{~mL})$ then treated with excess $\mathrm{CH}_{2} \mathrm{~N}_{2}-\mathrm{Et}_{2} \mathrm{O}$ at $0{ }^{\circ} \mathrm{C}$ for $1 \mathrm{~h}$. The reaction was allowed to warm to rt overnight then the solvent were evaporated and the residue was purified using a diol SPE cartridge with a $20 \%$ stepwise elutions from $100 \%$ hexanes to $100 \%$ EtOAc. Compound 3 ( $8.0 \mathrm{mg}, 98 \%$ yield) eluted with the $60 \%$ EtOAc/40\% hexanes wash. Stable yellow needles $\left(\mathrm{CHCl}_{3}\right) ; \mathrm{mp} 219-221{ }^{\circ} \mathrm{C}$ (Ginde et al., 1970); UV (MeOH) $\lambda_{\max }(\log \varepsilon) 239$ (4.25), 258 (4.29), 289 (3.72), 312 sh (3.41), 364 nm (3.57); IR $v_{\max }(\mathrm{NaCl}) 1729,1651,1622,1594,1485,1462,1455,1434,1409,1362,1293,1252$, 
1215, 1106, 1076, 1028, 968, 821, $730 \mathrm{~cm}^{-1}$; (+)-LRESIMS m/z (rel. int.) 297 (40), 329

(40), 351 (100); (+)-HRESIMS m/z 329.1030 $\left(\mathrm{C}_{18} \mathrm{H}_{17} \mathrm{O}_{6}[\mathrm{M}+\mathrm{H}]^{+}\right.$requires 329.1020).

\subsection{Crystallography}

Diffraction data were collected on a crystal of 3 at $295 \mathrm{~K}$ on a Rigaku AFC7R rotating anode four circle diffractometer using monochromated $\operatorname{MoK}_{\alpha}$ radiation $(\lambda=0.71069 \AA)$. Found tetragonal, space group $I 4_{1} / \mathrm{a}, a=14.660(2), c=29.248(1) \AA$. The structure was solved by direct methods using the program SIR-97 (Altomare et al., 1996) with atom positions and displacement parameters refined using SHELXL97 (Sheldrick, 1997) within the teXsan program package (Molecular Structure Corporation, 1997-2000). The final refinement to convergence was against $\mathrm{F}^{2}$ with 2770 unique reflections to give a final $R$-factor $(I>2 \sigma(I))$ of 0.056 and $w R$ (all data $)=0.199$. The non-hydrogen atoms were refined anisotropically and the $\mathrm{H}$-atoms placed in idealised geometries.

Crystallographic data for the structure reported in this paper have been deposited at the Cambridge Crystallographic Data Centre (CCDC No. 243683). Copies of the data can be

obtained, free of charge, on application to the Director, CCDC, 12 Union Road, Cambridge CB2 1EZ, UK (Fax: +44-1223-336033; email: deposit@ccdc.cam.ac.uk).

\section{Acknowledgements}

The authors thank Dr. Bob Coutts for assistance with plant taxonomy. R.A.D. gratefully acknowledges support provided by a New Researcher Grant from Griffith 
University and also thanks Prof. Ronald J. Quinn for his guidance and the use of his lab facilities.

\section{References}

Allen, F.H., Kennard, O., Watson, D.G., Brammer, L., Orpen, A.G., and Taylor, R. 1987. Tables of bond lengths determined by $\mathrm{x}$-ray and neutron diffraction. Part 1. Bond lengths in organic compounds. J. Chem. Soc., Perkin Trans. 2S1-S19.

Altomare, A., Foadi, J., Giavovazzo, C., Guagliardi, A., and Moliterni, A.G.G. 1996.

Solving crystal structures from powder data. II. Pseudo-translational symmetry and powder-pattern decomposition. J. Appl. Cryst. 29, 674-681.

Boonphong, S., Kittakoop, P., Isaka, M., Pittayakhajonwut, D., Tanticharoen, M., and Thebtaranonth, Y. 2001. Multiplolides A and B, New Antifungal 10-Membered Lactones from Xylaria multiplex. J. Nat. Prod. 64, 965-967.

Farrugia, L.J. 1997. ORTEP-3 for windows - a version of ORTEP-III with a graphical user interface (GUI). J. Appl. Cryst. 30, 565.

Ginde, B.S., Hosangadi, B.D., Kudav, N.A., Nayak, K.V., and Kulkarni, A.B. 1970.

Chemical investigations on Cassia occidentalis. I. Isolation and structure of cassiollin, a

new xanthone. J. Chem. Soc. C.1285-1289.

Greenberg, R.N., Bollinger, M.R., and Alivisatos, M.R. 1986. In vitro activity of piperacillin, ticarcillin, mezlocillin, ticarcillin-clavulanic acid, aztreonam, ceftazidime, azlocillin, cefoperazone, and thienamycin against Pseudomonas aeruginosa. Clinical Therapeutics 8, 655-657.

Groweiss, A., Cardellina, J.H., II, and Boyd, M.R. 2000. HIV-Inhibitory Prenylated Xanthones and Flavones from Maclura tinctoria. J. Nat. Prod. 63, 1537-1539. Hamasaki, T., Sato, Y., and Hatsuda, Y. 1975. Structure of sydowinin A, sydowinin B, and sydowinol, metabolites from Aspergillus sydowi. Agric. Biol. Chem. 39, 2341-2345. Ho, C.-K., Huang, Y.-L., and Chen, C.-C. 2002. Garcinone E, a xanthone derivative, has potent cytotoxic effect against hepatocellular carcinoma cell lines. Planta Med. 68, 975979.

Huneck, S. 2001. New results on the chemistry of lichen substances. Prog. Chem. Org. Nat. Prod. 81, 1-276.

Jayasuriya, H., Herath, K.B., Ondeyka, J.G., Polishook, J.D., Bills, G.F., Dombrowski, A.W., Springer, M.S., Siciliano, S., Malkowitz, L., Sanchez, M., Guan, Z., Tiwari, S., Stevenson, D.W., Borris, R.P., and Singh, S.B. 2004. Isolation and structure of antagonists of chemokine receptor (CCR5). J. Nat. Prod. 67, 1036-1038.

Law, K.-K., Chan, T.-L., Tam, S.W., and Shatin, N.T. 1979. Synthesis of pinselic acid and pinselin. J. Org. Chem. 44, 4452-4453.

Lin, C.N., Chung, M.I., Liou, S.J., Lee, T.H., and Wang, J.P. 1996. Synthesis and antiinflammatory effects of xanthone derivatives. J. Pharmacy Pharmacol. 48, 532-538. Macias, M., Gamboa, A., Ulloa, M., Toscano, R.A., and Mata, R. 2001. Phytotoxic naphthopyranone derivatives from the coprophilous fungus Guanomyces polythrix. Phytochemistry 58, 751-758. 
Malet-Cascon, L., Romero, F., Espliego-Vazquez, F., Gravalos, D., and FernandezPuentes, J.L. 2003. IB-00208, a new cytotoxic polycyclic xanthone produced by a marine-derived Actinomadura. I. Isolation of the strain, taxonomy and biological activites. J. Antibiot. 56, 219-225.

Minami, H., Kinoshita, M., Fukuyama, Y., Kodama, M., Yoshizawa, T., Sugiura, M., Nakagawa, K., and Tago, H. 1994. Antioxidant xanthones from Garcinia subelliptica. Phytochemistry 36, 501-506.

Molecular Structure Corporation 1997-2001. TeXsan for Windows, Version 1.06. MSC 9009 New Trails Drive, The Woodlands, TX 77381, USA.

Moppett, C.E. 1971. Revised structure for cassiollin: identity with pinselin. J. Chem. Soc. D.423-424.

Munekata, H. 1943. Bitter substance and coloring substance produced by Penicillium. I. J. Agric. Chem. Soc. Jpn. 19, 343-346.

Munekata, H. 1953. Some new metabolic products of Penicillium. II. J. Biochem. Jpn. 40, 451-460.

Peres, V., and Nagem, T.J. 1996. Trioxygenated naturally occurring xanthones. Phytochemistry 44, 191-214.

Peres, V., Nagem, T.J., and de Oliveira, F.F. 2000. Tetraoxygenated naturally occurring xanthones. Phytochemistry 55, 683-710.

Pretsch, E., Buhlmann, P., and Affolter, C. 2000 Structure Determination of Organic Compounds. Table of Spectral Data. Berlin, Heidelberg, New York: Springer-Verlag. Rocha, L., Marston, A., Kaplan, M.A.C., Stoeckli-Evans, H., Thull, U., Testa, B., and Hostettmann, K. 1994. An antifungal $\gamma$-pyrone and xanthones with monoamine oxidase inhibitory activity from Hypericum brasiliense. Phytochemistry 36, 1381-1385.

Schulz, B., Boyle, C., Draeger, S., Roemmert, A.-K., and Krohn, K. 2002. Endophytic fungi: a source of novel biologically active secondary metabolites. Mycol. Res. 106, 9961004.

Sheldrick, G.M., 1997. SHELXL97: Program for the refinement of crystal structures. University of Göttingen, Germany.

Smith, C.J., Morin, N.R., Bills, G.F., Dombrowski, A.W., Salituro, G.M., Smith, S.K., Zhao, A., and MacNeil, D.J. 2002. Novel sesquiterpenoids from the fermentation of Xylaria persicaria are selective ligands for the NPY Y 5 receptor. J. Org. Chem. 67, 5001-5004.

Solis, P.N., Wright, C.W., Anderson, M.M., Gupta, M.P., and Phillipson, J.D. 1993. A microwell cytotoxicity assay using Artemia salina (brine shrimp). Planta Med. 59, 250252.

Telange, R.P., Kudav, N.A., and Kulkarni, A.B. 1977. Chemical investigations on Cassia occidentalis Linn.: Part V. Synthesis of 8-carbomethoxy-1,7-dimethoxy-3methylxanthone, the dimethyl ether of Pinselin (Cassiollin). Ind. J. Chem. B. 15B, 553554.

Williams, J.B., Harden, G.J., and McDonald, W.J.F. 1984 Trees \& Shrubs in Rainforests of New South Wales \& Southern Queensland: University of New England Printery, Armidale. 
Table 1

NMR data for xanthones 1-3. ${ }^{a, b}$

\begin{tabular}{|c|c|c|c|c|c|c|}
\hline & \multicolumn{2}{|c|}{ Xanthone 1} & \multicolumn{2}{|c|}{ Xanthone 2} & \multicolumn{2}{|c|}{ Xanthone 3} \\
\hline & ${ }^{13} \mathrm{C}$ & ${ }^{1} \mathrm{H}$ (mult., $J$, int.) & ${ }^{13} \mathrm{C}$ & ${ }^{1} \mathrm{H}$ (mult., $J$, int.) & ${ }^{13} \mathrm{C}$ & ${ }^{1} \mathrm{H}$ (mult., $J$, int.) \\
\hline 1 & 119.9 & & 120.0 & & 120.2 & \\
\hline 2 & 150.0 & & 155.3 & & 151.9 & \\
\hline 3 & 123.2 & $7.29(\mathrm{~d}, 9.0,1 \mathrm{H})$ & 122.4 & $7.07(\mathrm{~d}, 9.0,1 \mathrm{H})$ & 119.5 & $7.61(\mathrm{~d}, 9.5,1 \mathrm{H})$ \\
\hline 4 & 118.4 & $7.43(\mathrm{~d}, 9.0,1 \mathrm{H})$ & 118.0 & $7.26(\mathrm{~d}, 9.0,1 \mathrm{H})$ & 119.5 & $7.65(\mathrm{~d}, 9.5,1 \mathrm{H})$ \\
\hline $4 a$ & 147.9 & & 147.4 & & 148.2 & \\
\hline $4 b$ & 156.9 & & 156.4 & & 157.0 & \\
\hline 5 & 109.2 & $6.91(\mathrm{~s}, 1 \mathrm{H})$ & 105.8 & $6.96(\mathrm{~s}, 1 \mathrm{H})$ & 109.3 & $6.93(\mathrm{~s}, 1 \mathrm{H})$ \\
\hline 6 & 146.5 & & 149.6 & & 147.1 & \\
\hline 7 & 107.1 & $6.78(\mathrm{~s}, 1 \mathrm{H})$ & 103.3 & $6.84(\mathrm{~s}, 1 \mathrm{H})$ & 107.3 & $6.81(\mathrm{~s}, 1 \mathrm{H})$ \\
\hline 8 & 159.7 & & 158.9 & & 159.8 & \\
\hline $8 \mathrm{a}$ & 109.0 & & 111.7 & & 108.8 & \\
\hline 9 & 173.5 & & 174.7 & & 173.4 & \\
\hline $9 \mathrm{a}$ & 119.6 & & 122.3 & & 119.7 & \\
\hline $1-\mathrm{CO}_{2} \mathrm{H}$ & 167.8 & $12.49(\mathrm{br} \mathrm{s}, 1 \mathrm{H})$ & 168.1 & $c$ & & \\
\hline \multirow[t]{2}{*}{$1-\mathrm{CO}_{2} \mathrm{CH}_{3}$} & & & & & 166.8 & \\
\hline & & & & & 52.1 & $3.83(\mathrm{~s}, 3 \mathrm{H})$ \\
\hline $2-\mathrm{OH}$ & & $9.96(\mathrm{br} \mathrm{s}, 1 \mathrm{H})$ & & c & & \\
\hline $2-\mathrm{OCH}_{3}$ & & & & & 56.7 & $3.84(\mathrm{~s}, 3 \mathrm{H})$ \\
\hline $6-\mathrm{CH}_{3}$ & 21.8 & $2.41(\mathrm{~s}, 3 \mathrm{H})$ & & & 21.8 & $2.42(\mathrm{~s}, 3 \mathrm{H})$ \\
\hline $6-\mathrm{CH}_{2} \mathrm{OH}$ & & & 62.4 & $4.59(\mathrm{~d}, 5.5,2 \mathrm{H})$ & & \\
\hline & & & & $5.43(\mathrm{t}, 5.5,1 \mathrm{H})$ & & \\
\hline $8-\mathrm{OCH}_{3}$ & 56.0 & $3.86(\mathrm{~s}, 3 \mathrm{H})$ & 55.9 & $3.86(\mathrm{~s}, 3 \mathrm{H})$ & 56.1 & $3.87(\mathrm{~s}, 3 \mathrm{H})$ \\
\hline
\end{tabular}

${ }^{a}$ Assignments were determined by gCOSY, HSQC, gHMBC and ROESY data analysis.

${ }^{b}$ Spectra were recorded in DMSO- $d_{6}$ at $30^{\circ} \mathrm{C}$.

${ }^{c}$ Signals not observed. 

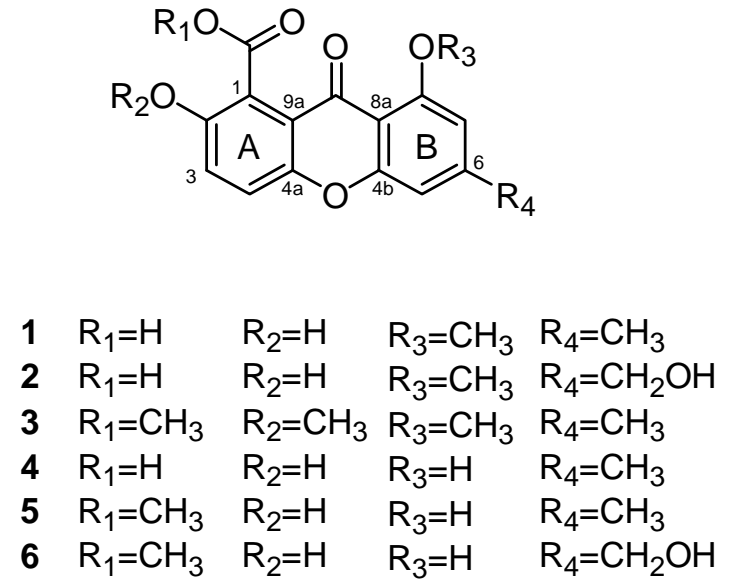

Fig. 1. Structures for xanthones 1-6.

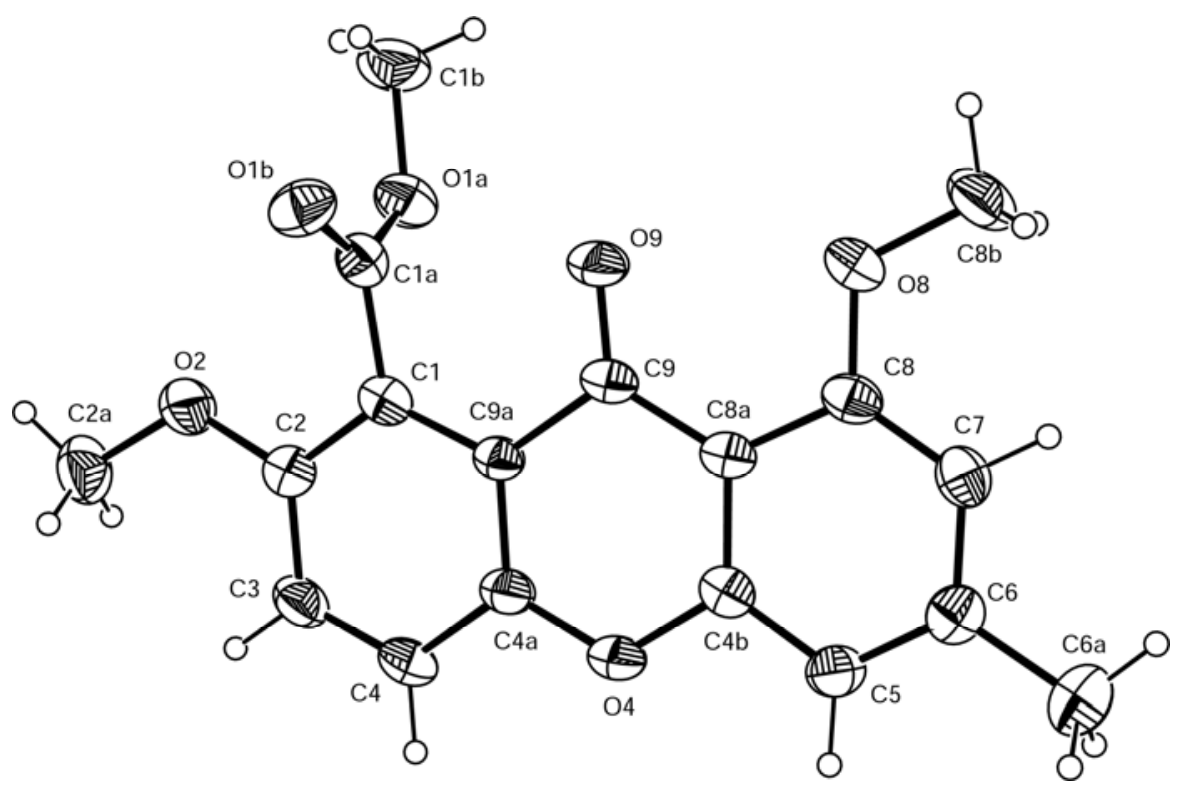

Fig. 2. ORTEP plot for xanthone 3. 